https://doi.org/10.18485/analiff.2020.32.2.1 94(497.11)"1914/1918"

Милица М. Спремић Кончар*

Originalni naučni rad

Универзитет у Београду

Филолошки факултет

Primljen: 12.06 .2020

Prihvaćen: 18.08 .2020

\title{
„ХРАБРА МАЛА СРПСКА АРМИЈА": СРБИ У ОЧИМА ЧЛАНИЦА СТРАНИХ МЕДИЦИНСКИХ МИСИЈА У ПРВОМ СВЕТСКОМ РАТУ
}

\begin{abstract}
Ослањајући се на појам балканизма Марије Тодорове, овај рад се бави фрагментима из писама, дневника и мемоара лекарки и болничарки, чланица страних медицинских мисија у Србији у Првом светском рату. Сакупљени у књизи Странкиње о српском војнику и Србији у Великом рату, текстови показују колико се мишљења и ставови њихових ауторки разликују од доминантног дискурса времена у којем су настали. Уместо презривих и ниподаштавајућих ставова који преовлађују у писаним изворима о овом делу Европе, ауторке заступљене у овој књизи показују поштовање и разумевање према Србима, а нарочито су импресиониране српском контраофанзиовом којом је у децембру 1914. године ослобођен Београд после свега тринаест дана аустријске окупације, Србима као добрим пацијентима, њиховим патриотизмом и хуманим односом према заробљеницима, њиховом љубављу према дому и породици, песми и игри, и њиховом оданошћу православној вери.
\end{abstract}

Кључне речи: Први светски рат, Србија, балканизам, стране лекарке и болничарке

\section{Увод}

О болном и трагичном искуству Првог светског рата за Србе и Србију, век после његовог завршетка, српска читалачка публика у прилици је да се подробније упозна, између осталог, и кроз низ занимљивих и вредних наслова из едиције Србија 1914-1918, коју заједнички објављују Радио телевизија Србије и новосадска издавачка кућа Прометеј. До сада је у три кола објављено неколико десетина наслова домаћих и страних аутора. Међу страним ауторима много је лекара и медицинског особља који су током Првог светског рата ра-

* m.spremickoncar@gmail.com 
дили у болницама у Србији, а један део њих се са српском војском и цивилима и повлачио преко Србије, Црне Горе и Албаније, у јесен и почетком зиме 1915. године. О тим суровим данима искушења многи од њих су оставили писана свдочанства, до данас углавном непозната српској јавности, а нека од њих, објављена у едицији Србија 19141918 јесу: Србија у рату 1914-1916. Катарине Штурценегер (Сatharina Sturzeneger, La Serbie en guerre 1914-1916), Пламени мач у Србији и другде Мејбел Синклер Стобарт (Mabel St. Clair Stobart, The Flaming Sword in Serbia and Elsewhere) и Са женском јединицом у Србији, Солуну и Севастопољу Изабел Емзли Хатон (Isabel Emslie Hutton, With a Woman's Unit in Serbia, Salonika and Sebastopol). Ова дела преносе непосредна искуства својих ауторки са ратом захваћеног Балкана и публици у њиховим земљама откривају до тада мало познату и углавном негативно описивану балканску државу Србију, у посве другачијем, веома позитивном светлу, као храбру и достојанствену земљу чији је народ спреман да за своју слободу и независност плати најскупљу цену.

Међу најскорије објављеним насловима из едиције Србија 19141918 јесте и збирка одломака из писане заоставштине чланица страних медицинских мисија у Првом светском рату у Србији, насловљена Странкиње о српском војнику и Србији у Великом рату, коју је прошле године приредио Ратомир Дамјановић. У питању су, дакле, фрагменти из писама, дневника и сећања странкиња, учесница Првог светског рата у Србији. Осим што се наша публика на једном месту упознаје са значајним бројем хуманитарки које су задужиле Србију у неким од најтежих тренутака њене историје, нарочита врлина оваквог приступа јесте у томе што осветљава сродне и заједничке, без изузетка повољне и похвалне ставове о Србима и Србији у незапамћеној агонији Првог светског рата. Такви ставови представљају радикални отклон од онога што Марија Тодорова у свом утицајном делу Имагинарни Балкан (Maria Todorova, Imagining the Balkans, 1999) назива дискурсом балканизма. Дискурс балканизма може се дефинисати као негативни стереотип о Балкану присутан у Западној култури и у значајној мери условљен политиком. У британској култури први путописи о Балкану настају у осамнаестом, а њихов број расте у наредном, деветнаестом веку, када се формира и учвршћује негативни стереотип 
о Балкану. Начелан став Енглеза према европском делу Отоманске царевине Тодорова описује речима ,природна емпатија са владаоцима и традиционална нетрпељивост према муслиманима, али је веома често први сентимент умео да превлада" (Todorova 1999: 163). Такав став постаје још актуелнији после 1830. године, када је Британија, као најважнија светска индустријска и трговачка сила, због равнотеже моћи, почела да се залаже за очување интегритета и неповредивости Отоманског царства. Оваквим курсом Британије на спољном плану објашњава се видљива политизација путописа насталих у деветнаестом веку: њихови аутори јасно излажу своје политичке ставове, који су готово увек сагласни са званичном политичком линијом (1999: 169). Када је реч о покореном хришћанском живљу на Балкану, уз ограду да свако уопштавање подразумева изузетке, Тодорова наводи (1999: 173) да су ,аристократе углавном биле туркофили, док је либерална средња класа била наклоњенија хришћанским народима". Важан изузетак представљају угледне припаднице више класе, Аделина Полина Ирби и Џорџина Мјур Мекензи, које су у свом делу Путовања по словенским крајевима европске Турске (Adeline Pauline Irby and Georgine Muir Mackenzie, Travels in the Slavonic Provinces of Turkey-in-Europe, 1866) британску публику упознале са дотада практично непознатом темом, са патњом потчињених словенских народа, и вероватно утицале на Вилијама Гледстона који је ревидирао своје туркофилске ставове (Момчиловић 1993: 166), како би у јавном деловању почео да указује на то да се не сме игнорисати стање у којем се налазе потчињени народи у Отоманском царству (Todorova 1999: 175). Тодорова, међутим, подсећа (1999: 181) на то да, упркос угледу Ирбијеве, Мекензијеве, Гледстона и још неких јавних делатника, њихови ставови ипак нису били нарочито утицајни, односно да је доминантни дискурс, чак и када је критиковао отоманску власт као самовољну, деспотску и нецивилизовану, избегавао расне погрде муслимана или Турака, док је Јужне Словене отворено сматрао неспособним да се успешно и самостално развијају.

Захваљујући оваквом погледу на ствари, почетком двадесетог века на Западу је већ била изграђена неповољна слика о Балкану, а потом је даље учвршћивана кроз трагичне догађаје који су уследили. Репутација Срба додатно је нарушена убиством краља Александра 
Обреновића и краљице Драге, маја 1903. године у Београду, а Србија је отворено проглашавана кривом и за атентат на Франца Фердинанда у Сарајеву, односно за избијање Првог светског рата. Тодорова наводи резултате једног истраживања (1999: 209) из којег се види да су у немачким и аустријским ратним извештајима о Балкану од 1912. до 1918. године обилато коришћене уопштавајуће етикете као што су „оријентално” - „да означи прљавштину, пасивност, непоузданост, мизогинију, склоност ка сплеткарењу, неискреност, опортунизам, лењост, сујеверје, летаргију, тромост, неефикасност, неспособну бирократију” - и „балканско" - у смислу „окрутности, неотесаности, нестабилности и непредвидивости". Уколико се имају на уму ови и многобројни други примери презривих ставова Запада о овом делу Европе, ${ }^{1}$ утолико су вреднија сведочанства чланица страних медицинских мисија о Србима и Србији, јер су запањујуће дисонантна у односу на доминантни дискурс времена у којем су настала. Из њихових записа Србија израња као откровење у мржњом премреженој Европи, као светао пример непристајања на окупацију и пример отпора Аустријанцима, Немцима и Бугарима, а српски народ се указује као храбар, издржљив, захвалан на указаној помоћи, добронамеран, стрпљив и достојанствен у патњи и поразу. Записи ауторки заступљених у књизи Странкиње о српском војнику и Србији у Великом рату по-

1 Тодорова (1999: 205-6) наводи негативне ставове неколико енглеских аутора из овог периода. Хенри Де Винт (Harry de Windt) своје путовање по Балкану и европском делу Русије назива путем „по дивљој Европи”, а пределе које је посетио „дивљим земљама између Јадранског и Црног мора које живе у безакоњу”, и „жариштима криминала и хајдучије”. Гоф и Фосет (Goff/Fawcett) у белешкама о Македонији помињу „незрели, непросвећени интелект” македонских сељака, а о карактеру Македонаца кажу: „Репресија и потпуни недостакак образовања ... створили су лукавост и природну склоност ка дивљаштву”. Х. Н. Брејлсфорд (H. N. Brailsford) у сличном тону настоји да да̂ синтетички осврт на народе Балкана: „Покушао сам да, колико то један Европљанин може, будем толерантан и према хришћанима и према Турцима, имајући стално на уму разлику између норми које владају на Балкану и оних у Европи. У земљи у којој сељак оре носећи пушку на леђима, где властодршци остају на власти захваљујући способности да по потреби и убијају, где се претпоставља да хришћански црквени велокодостојници организују политичка убиства, живот има само релативну вредност, а убиство доноси само релативну кривицу. По крволочности се расе на Балкану међусобно не разликују много - оне су производ вековне азијатске власти". 
кривају све фазе њиховог рада: „[д]олазак медицинских мисија у Сpбију, рад у болницама, рат са тифусом, голгот[у] повлачења, злочин[е] агресора, боравак и рад у егзилу, повратак кући (Дамјановић 2019: 11). Готово сви записи концентришу се око неколико тема којима су ауторке очигледно биле фасциниране дошавши у Србију, не само далеку и непознату, већ и веома неповољно представљану земљу у јавности Велике Британије, Канаде, Аустралије и Сједињених Америчких Држава, одакле су потицале. ${ }^{2}$ Те теме су кратка аустријска окупација Београда у децембру 1914. године и брза српска контраофанзива, српски војници као добри и захвални пацијенти са пуним поверењем у стране лекарке и болничарке, српски патриотизам, хумани однос према аустријским заробљеницима, љубав према дому и породици, љубав према песми и игри и оданост православној вери. Циљ овога рада јесте да укаже на емпатију ауторки према Србима и Србији, на позитиван и пријатељски став према земљи и народу који то истински завређује.

\section{Аустријска окупација Београда}

Американка Агнес Гарднер (Agnes Gardner), медицинска сестра у болници доктора Едварда Рајана (Edward Ryan) у Београду, била је сведок аустријске окупације Београда од 2. до 15. децембра 1914. године, уласка аустријске војске уз музику њихових оркестара, али и брзог повратка Београда у српске руке: „Срби су окружили Београд са свих страна. Аустријанци су буквално били одсечени. Једини излаз био им је преко реке Саве, у коју су били сатерани и устрељени. Заробљено је шездесет хиљада Аустријанаца" (Гарднер 1019: 40). ${ }^{3}$ Америчка историчарка Присила Хардинг (Priscilla Harding) цитира одломак из дневника медицинске сестре Мери Гледвин (Mary Gladwin), такође из болнице доктора Едварда Рајана у Београду, која доноси и

2 Осим ауторки из англофоних земаља, у књизи је заступљена и Швајцаркиња Катарина Клара Штурценегер, Норвежанка Ингеборг Стин-Хансен (Ingeborg Steen-Hansen), Чилеанка Сузан Гевара (Susana Guevara), неколико Рускиња и Францускиња.

3 Сви цитати у овом раду наведени су према преводима објављеним у књизи Странкиње о српском војнику и Србији у Великом рату. У парентезама су, ради прегледности, навођена презимена ауторки појединачних фрагмената поменуте књиге. 
једну анегдоту о аустријској окупацији Београда. Одмах по српском ослобођењу, у болницу је дошао један млади српски капетан, опијен војним успехом:

Кратка аустријска окупација, приметио је весело, неће бити убележена у аналима града. Аустрија и Србија користе различите календаре, објаснио је, који се разликују за дванаест дана. Аустријанци су заузели Београд другог децембра по реформисаном календару, а Срби су га повратили другог децембра по старовременском календару. Што се историје тиче, закључио је, окупација се никада није десила. (Хардинг 2019: 46)

Енглеска болничарка Моника Стенли (Monica Stanley) такође бележи да су се Аустријанци у Београду задржали тринаест дана и да су приликом повлачења доживели велике губитке, док Швајцаркиња Катарина Клара Штурценегер повратак Београда у српске руке назива „чудом српске војске”:

Какав успех за малу српску војску! Да, дешавају се још увек чуда. Пред својим чудом цела српска нација склапа руке и из свег срца кличе „Хвала Богу! Хвала Богу”. Главе се сагињу и сузе захвалности теку. Цео народ, краљ, краљевић сједињују се у својој захвалности. (Штурценегер 2019: 49-50)

\section{Српски војници као пацијенти}

Држање српских војника у најизазовнијим тренуцима њихових живота, захвалност страним медицинским мисијама и безгранично поверење у њих не промичу проницљивим очима лекарки и болничарки, и оне им без изузетка одају признање. Агнес Гарднер пише: „Као пацијенти, њихово понашање је задивљујуће, издржавали су муке док су лекари тражили метке и шрапнеле, од њих сте само чули „Добро"” (Гарднер 1019: 39). Енглеска болничарка Амалија Пибоди Тајлстон (Amelia Peabody Iilestone) додаје: „Они су најхрабрији војници у Европи. Знају да се боре за своја огњишта и своје породице и радије гину него да буду заробљени (Тајлсон 2019: 58), а Моника Стенли потврђује: „Рањеници су бескрајно захвални за сваку помоћ 
„ХРАБРА МАЛА СРПСКА АРМИЈА“: СРБИ У ОЧИМА ЧЛАНИЦА СТРАНИХ ...

која им се пружи. Зову нас 'сестро' и, често, “добра сестро”' (Стенли 2019: 70). Шкотска лекарка Изабел Емзли Хатон (Isabel Emslie Hutton) која је највише времена провела у болници у Врању, бележи:

Срби нису никад ни за тренутак доводили у питање наше мишљење или наше умеће; то је било необично у земљи где жене обрађују земљу, где је мушкарац господар и газда и јаше док жена иде пешке поред њега. Саопштили бисте што је блаже могуће да око или нога морају да се одстране. „Не мари ништа,” рекли би незаинтересовано, „ако ви мислите тако, онда урадите то.” (Хатон 2019: 79).

Поверење у жене хирурге потврђује и енглеска лекарка Франсес Вејкфилд (Frances Wakefield): „[О]ни су више волели нас од војних лекара - тврдили су да су жене хирурзи пажљивије, да нису никада грубе и да су уопште нежније и стрпљивије" (Вејкфилд 2019: 118). О храбрости српских рањеника сведочи и Аустралијанка Мери Џозефина Бедфорд (Mary Josephine Bedford) која је возила санитетско возило Болнице шкотских жена током битке на Кајмакчалану: „На овим вожњама амбулантним возилима често се показивала храброст и витештво српског војника. Трпео је бол и хладноћу без гласка, а после веома мучног путовања преко неравног, џомбастог терена, са осмехом би захвалио сестри-возачу на пажљивој вожњи" (Бедфорд 2019: 280). Да се српски војници никада и ни на шта не жале као болесници примећују Амалија Пибоди Тајлстон (2019: 347) и Ингеборг Стин-Хансен (2019: 326), а Аустралијанка Олив Келсо Кинг (Olive Kelso King) у писму оцу као да прави синтезу свега поменутог:

Толико желим да помогнем овим јадним људима, они су толико стрпљиви и не жале се, и толико једноставни, доброћудни и љубазни. Као што сам ти често рекла, човек би могао да их опише као водећу расу света правих џентлмена, јер шта чини џентлмена него благост, учтивост, каваљерство, храброст и несебичност, херојска стрпљивост у најстрашнијим искушењима, и шта може да буде већа несрећа него изгубити своју земљу, свој дом и немати вести о својима? (Кинг 2019: 320) 
Уз похвална запажања о српским пацијентима, лекарке и болничарке често говоре о начинима на које су се са њима споразумевале. Све, без изузетка, српски језик сматрају тешким. Мејбел Торп Бордман (Mabel Thorp Boardman), Изобел Poc (Ishobel Ross) и Амалија Пибоди Тајлстон помињу да су га училе, али је већина знала тек неколико најпотребнијих речи. Агнес Гарднер бележи:

Језик је био тежак, али смо успели да научимо речник корисних речи и свакодневних израза. Граматику нисмо ни покушали. Такве речи као што су „боли”, „нога”, „рука”, „глава”, „око”, ,језик”, „зуби”, „завој”, „спава”, „вода”, „чај”, „лези”, „седите”, „добро јутро”, „лаку ноћ”, „пријатно спавали”, „фала”, биле су нам међу првима. (Гарднер 2019: 39).

Много је коришћена и невербална комуникација:

Причамо помоћу руку и уз много осмеха. Они кажу „dobra sester” - „dobra English”, ја кажем „dobra” - и онда сви кажемо „dobra”. Уопште нисам огуглала на ране. Није ми мука да их видим нити ми се гади, само ми је јако жао и увек се помало разнежим и потапшем их по руци и кажем „dobar voynic” а они кажу „dobra sester.” (Дирмер 2019: 129)

Изабел Емзли Хатон даје, чини се, најбољу слику споја вербалне и невербалне комуникације:

А како су сестре разговарале са Србима? Неке од нашег особља које су учествовале у повлачењу кроз Албанију знале су мало српски, али пошто је то врло тежак језик и ниједан други не помаже да се он научи, напредак је у почетку био спор. Многе сестре нису никада научиле више од пола туцета речи и изговарале су их сасвим погрешно; стога су морале да говоре својим језиком, а Срби су их, обраћајући пажњу на тон гласа и израз лица, савршено разумели. Сви смо открили да се можемо споразумевати савршено са „добро” и „не добро” и „боли”, а остало се постизало мимиком, одмахивањем или климањем главе, или показивањем прстом на болно место. Било је необично открити да ови прирпости људи, који нису знали да читају ни да пишу, нити су осећали потребу за тим, 
„ХРАБРА МАЛА СРПСКА АРМИЈА“: СРБИ У ОЧИМА ЧЛАНИЦА СТРАНИХ ...

разговарају тако изражајно и тако се добро служе мимиком, да су сестре ускоро знале њихове животне приче, а пацијенти, са своје стране, сваку наредбу сестре.” (Хатон 2019: 193-4)

Чланице страних медицинских мисија умеју и да уз дозу доброћудног хумора примете неке њима несхватљиве, а иначе пословичне српске навике. Тако докторка Кетрин Макфејл (Katherine MacPhail) о својим пацијентима пише: ,Стално су се бунили што су прозори отворени и покривали су се ћебетом преко главе, а ноге су им остајале непокривене, па када смо обилазиле одељење, уместо њихових глава виделе смо низ огромних стопала" (Мекфејл 2019: 99). Искуство докторке Франсес Вејкфилд је слично: „Из неког необјашњивог разлога ти војници са села мрзели су свеж ваздух, па се чак и плашили проветравања. Стално смо водиле борбу да отворимо прозоре и ослободимо се страшне загушљивости коју су они волели” (Вејкфилд 2019: 118), а Л. Е. Фрејзер (2019: 119) (L. Е. Frazer), описујући болницу у Нишу, кратко додаје: „Свуда су двоструки прозори добро затворени, ови људи не воле превише проветравања."

\section{Српски патриотизам}

Српски патриотизам оставља дубок утисак на стране лекарке и болничарке и чини се да управо из дивљења према њему потиче осећање задовољства и поноса ових храбрих жена што се налазе међу Србима. Катарина Штурценегер (2019: 50-1) бележи свој утисак: „Да, народ који се тако бори за своја најдрагоценија добра, за своје огњиште и своју отаџбину, заслужује да их сачува. Остала сам у чврстом убеђењу да тај народ неће бити побеђен," а Амалија Пибоди Тајлстон апелује:

Србима се треба дивити због њиховог патриотизма, храбрости, стрпљења и радиности, али заслужују љубав због једноставности, захвалности и љубазности које дарују широког срца. ... Они су извојевали величанствене победе и ми, из нашег обиља, морамо помоћи малој нацији која доприноси узвишеном циљу, победи над тиранијом и милитаризмом. (Тајлстон 2019: 59) 
Олив Олдриџ (Olive Aldridge) надахнуто сумира:

Српски војник је храбар. У храбрости га нико не може надмашити, неустрашив је и са презиром гледа на смрт - и то не зато што жели да умре више него што то жели било ко пре него што дође његово време. Он воли живот и весеље и радост, али када је пред њим дужност, а испречи се смрт, он наставља право - не само без оклевања, већ без промене израза на лицу. Он зна како да умре и то је више од храбрости - то се мери са узвишеношћу. (Олдриџ 2019: 171)

Спознаја карактера српског родољуба појачава осећај дужности чланица страних медицинских мисија и уверење да су на правом месту. Тако Мери Гледвин, у телеграму пријатељима у Америци у јесен 1915. године поручује да је још у Београду, у болници доктора Едварда Рајана, и да не брину: „Ја сам добро колико могу да будем, савршено безбедна, имам изобиље јела и драго ми је што сам овде" (Хардинг 2019: 47), а Мејбел Дирмер (Mabel Dearmer), из болнице Стобарт у Крагујевцу, такође у писму пријатељу, каже:

Одлучила сам да останем овде док се рат не заврши. Зар не мислиш да би то било добро дело? Не могу да поднесем да будем код куће уместо да се овде бавим правим послом.

Била сам знатижељна да чујем твоје вести из Лондона. O, како сам срећна што нисам тамо! Мислим да не бих лако поднела да боравим под кровом - након овог живота овде." (Дирмер 2019: 116)

Судбина је нажалост хтела да се и сама зарази тифусом у чијем је лечењу помагала Србима и да заувек остане да почива у Србији. Из једног каснијег писма види се да је била свесна те опасности, али да ју је у потпуности прихватала: „Човек једног дана мора стати, а ја лично бих радије да „станем” овде, током овог рада, него било где другде на овом свету. Нема ничег ужасног нити мучног у тифусу - већину времена спаваш или једноставно одлуташ сасвим тихо у непознато" (Дирмер 2019: 132). После преласка преко Албаније и евакуације из Медове, најпре у Италију, а онда преко Француске у Британију, неке чланице медицинских мисија спознале су једно још необичније 
„ХРАБРА МАЛА СРПСКА АРМИЈА“: СРБИ У ОЧИМА ЧЛАНИЦА СТРАНИХ ...

осећање - тугу што су се вратиле на сигурно и растале од Срба. Олив Олдриџ (2019: 252) то најбоље описује: „Вратили смо се нашем дому, пријатељима и удобности; ипак, био је то тужан повратак кући, и радо бисмо се, да смо могли, вратили назад. Наше мисли су се стално враћале на српске војнике које смо оставили на тој негостољубивој албанској обали."

\section{Хумани однос према аустријским заробљеницима}

Чланице страних медицинских мисија биле су истински дирнуте и хуманим односом Срба према аустријским заробљеницима, и то не пропуштају да нагласе. Ингеборг Стин-Хансен (2019: 75) положај аустријских заробљеника у Србији назива „чудним” јер су имали слободу кретања, те су се у Ваљеву, где је службовала, могли видети како леже на сунцу, пију кафу у ресторанима или седе у парковима и разговарају, а немачка и аустријска имовина у Србији није уништавана. На другом месту (2019: 133-4) ова ауторка проговара о својеврсном парадоксу рата, помињући свој разговор са једним лекаром, аустријским заробљеником, који је са још неколико колега остао у Ваљеву после повлачења аустријске војске, да би лечио око хиљаду људи од тифуca, а Мејбел Дирмер (2019: 115) била је сведок сличних околности у Крагујевцу, где је главни доктор у српској болници био аустријски заробљеник коме је лекарска етика налагала да настави да помаже болесницима, те је сам неговао и лечио две стотине рањеника. Л. Е. Фрејзер (2019: 121) потврђује да су Срби „били племенити у третирању својих заробљеника.”, а леди Пеџет о стању у болници у Скопљу бележи:

Од децембра до јануара био је бескрајан проток српских и аустријских рањеника. Аустријанци су били додатно оптерећење у материјалном смислу. Срби су били изузетно великодушни у односу на ове аустријске рањенике и нису поставили никакву забрану да их третирамо на исти начин на који смо третирали њихове људе. Чак и сада је немогуће заборавити задивљјујуће витештво које је Србија показивала према својим заробљеницима када она и сама није имала за неопходне потребе. (Пеџет 2019: 162) 
Зато и не треба да чуди запажање Олив Олдриџ (2019: 172) да су аустријски заробљеници „одавали поштовање Србима као војницима. „Нема бољих војника од њих”, говорили су.”

\section{Љубав према дому и породици}

Љубав Срба према дому, породици и родном селу један је од најјачих утисака које су чланице страних медицинских мисија понеле из Србије. Чувена Флора Сендс (Flora Sandes), енглеска болничарка и прва жена официр у српској војсци, оставља дирљив запис пред полазак из Струге у изгнанство у Албанију:

То ме је силно растужило, а како је морало бити њима, који тако страсно воле своју отаџбину да никад не желе да иду из ње, јер српски сељак се осећа изгубљен и болестан од чежње за својим завичајем кад се удаљи само десет-петнаест километара од њега. ...

Много је писано о физичким патњама војника у ово време; они могу издржати глад и муке, али ова чежња за отаџбином и очајање, осећање да су без пријатеља, војска у изгнанству, не знајући шта је са њиховим драгим у Србији то је, у ствари, сломило њихова срца и одузело им поуздање више него друге патње. Они су гледали на мене готово као на себи равног, и официри и војници често су ми причали о својим кућама, тако да сам скоро осећала као да је моја отаџбина прегажена, и да смо истерани из ње. (Сендс 2019: 210)

На другом месту (2019: 340) Флора Сендс у опису прославе Божића помиње да су Срби настојали да буду весели, али да су заправо били „врло тужни и пуни чежње за отаџбином, не знајући где њихове породице проводе Божић и да ли ће их икад више видети.” Олив Келсо Кинг (2019: 320) описује тугу српских војника јер немају вести од најближих: „То је за њих изузетно тешко, јер они су народ који много воли свој дом. Све њихове мисли су управљене њиховим малим домовима, и њиховом драгом, вољеном сну о уједињеној Србији”. Ипак, најпоетичније о љубави Срба према дому и породици пише Изабел Емзли Хатон: 
„ХРАБРА МАЛА СРПСКА АРМИЈА“: СРБИ У ОЧИМА ЧЛАНИЦА СТРАНИХ ...

Болнице су ускоро почеле да се пуне Србима, јер су и они подлегали маларији и дизентерији и многи од њих су умрли не видевши своју вољену земљу. Били су тужни брђани и говорили су само о својој лепој земљи и селу, и дању и ноћу су сањали о повратку кући. Нема река или планина, нити птица и цвећа - у ствари, нема ни сунца ни месеца као што су они у Србији. ...

Много су се бојали за безбедност својих жена и деце, од којих је већина још увек била у Србији. Стално су мислили на зверства која би могао да почини мрски непријатељ, Бугари, па су њихове душевне патње биле веома велике; и имали су добре разлоге за бригу. (Хатон 2019: 289-90)

\section{Љубав према песми и игри}

Када докторка Елси Инглис (Elsie Inglis) свој рад у болници у Крушевцу опише као „чудну мешавину туге и среће” (Инглис 2019: 203), она запажа нешто о чему сведоче и друге чланице страних медицинских мисија. То су контраст између ужасних патњи које је Србија подносила и природних лепота њених предела, и контраст између претешких услова у којима се настојало помоћи рањенима и болеснима и животне енергије оних који су се опорављали. Та животна енергија огледала се понајпре у љубави Срба према песми и националној игри, колу. Кетрин Мекфејл сведочи да су се пацијенти у болници у Београду увече окупљали око грамофона, певали, а понекад и играли, Мејбел Дирмер (2019: 131) пише да „[и]грају у кругу правећи све време неку врсту корака, и такође певају, дуге саге о прошлим ратовима, у чулној хармонији која је прелепа", а Мејбел Синклер Стобарт (2019: 104) описује хватање Срба у коло уз звук гусала, виолина или флауте, и једно посебно вече, када су се сестре, доктори и неговатељи придружили колу, које је увек ,достојанствено, сасвим лишено наглости, вулгарности или чулности.” Ингеборг Стин-Хансен (2019: 150) бележи да се коло повело и током вечерње паузе на путу од Битоља до Струге, који је она прешла у једном војном транспортном аутомобилу, а хирург, др Розали Мортон (Rosalie Morton), у надахнутом сећању на болницу на Солунском фронту, описује моћ музике: 
Француски пацијенти су на својим носилима лежали у грчу, стиснутих песница, подигнутих колена, лица побледелих од бола. Срби су запевали своје љубавне песме, серенаде и успаванке; веселе народне песме; корачнице, чврсте и мирне; псалме, нежне и утешне. Рањени Французи су се опустили; полако су исправили колена; постепено су отворили стиснуте шаке; у лице им се вратило руменило. По први пут сам видела психолошки ефекат музике: смиривање живчаног система и стимулацију крвотока. .....

Нико није умро, музика је код многих створила плиму живота и снаге за опоравак и отела их од смрти којој би се иначе препустили те ноћи. (Мортон 2019: 333-4)

Уз љубав према песми и игри, стране лекарке и болничарке често се осврћу на богату српску епску традицију која их је одржала током вишевековног ропства под Турцима, напомињући да је она још увек продуктивна, односно да се стварају песме и о недавним српским победама у Балканским ратовима, па чак и о Великом рату. Изабел Емзли Хатон (2019: 290) наводи стихове најпознатије лирске песме из Првог светског рата, „Тамо далеко.” Помиње се и значај гуслара за очување колективног памћења, а Мејбел Синклер Стобарт, уз дозу типичног енглеског хумора, предочава својој читалачкој публици колико може трајати певање српских гуслара:

Мудро је оставити довољно времена за српски концерт, пошто ниједан гуслар који држи до себе неће пропустити да опева бар неколико векова националне историје у једном наступу. Један гуслар нас је довео у неприлику током свог концерта. Пробали смо на разне начине. Он није попуштао, и ја схватих, очајна, да планира да ослободи своју земљу од турске тираније, што је значило још петсто година. (Стобарт 2019: 103)

Осим о епској традицији, поједини аутори остављају и записе о српској историји. Алис и Клод Аскју (Alice and Claude Askew) и Изабел Емзли Хатон пишу о краљевићу Марку, Милдред Стејли (Mildred Staley) почиње од досељавања Срба на Балканско полуострво, а Олив 
„ХРАБРА МАЛА СРПСКА АРМИЈА“: СРБИ У ОЧИМА ЧЛАНИЦА СТРАНИХ ...

Олдриџ настоји да објасни место Косовске битке у српској историји и дуге векове ропства у Отоманској империји, после којих је, почетком деветнаестог века, започета борба за ослобођење.

\section{Оданост православној вери}

Православна вера и ритуали такође остављају снажан утисак на стране лекарке и болничарке. Фрагменти у књизи Странкиње о српском војнику и Србији у Великом рату садрже описе највећих празника - Ускрса, Божића и слава - али и обреда у војсци, сахрана и помена. Мадлен де Беноа Сигоаје (Madeleine de Benoit Sigoyer) дочарава пролећну атмосферу Ускрса, ускршњи поздрав „Христос васкрсе” „Ваистину васкрсе”, раздрагану децу која се куцају ускршњим јајима и богат празнични ручак чији је највећи деликатес печена јагњетина (Сигоаје 2019: 175). О Божићу, осим Мадлен де Беноа Сигоаје, пишу и Алис и Клод Аскју, Мери Џозефина Бедфорд и Флора Сендс: помињу се лепоте зимског амбијента, украшени домови, обичај сечења Бадњака и уношења у кућу, посна вечера на Бадње вече, слама на подовима и бацање ораха у углове собе, као и тродневно празновање (Сигоаје 2019: 175-7). Има, наравно, и призора празника усред ратног ужаса, по пристизању десетковане српске војске у Љеш (Аскју 2019: 211), као и оних са ратних положаја (Бедфорд 2019: 280; Сендс 2019: 339-40). Надахнут опис славе оставља Мадлен де Беноа Сигоаје (2019: 105-7) уз напомену да подсећа на ,антички породични култ Грка и Римљана," да су најважнији симболи овог празника жито и вино, колач и свећа, да свештеник долази у кућу ради славског обреда, да потом пристижу гости и да се слави три дана. Изабел Емзли Хатон (2019: 207) описује како је своју славу у болници прославио један од њихових пацијената, а од важних српских празника помињу се и Ђурђевдан и Видовдан (Сигоаје 2019: 153-6). Елси Инглис (2019: 8992) оставља вредно сведочанство о ритуалу освећења Чесме женама Шкотске у Младеновцу, а Мадлен де Беноа Сигоаје (2019: 111-12) о свечаности полагања заклетве Застави у војсци. Изабел Емзли Хатон (2019: 267-9) описује сахрану госпође Харли, једне од најпожртвованијих жена у њеној болници, а Моника Стенли (2019: 71) помен на гробљу у Крагујевцу. 


\section{Закључак}

Двострука је вредност фрагмената из писама, дневника и сећања странкиња, учесница Првог светског рата у Србији, сакупљених у књизи Странкиње о српском војнику и Србији у Великом рату. Прво, они потврђују познату историјску чињеницу о многим медицински обазованим женама, лекаркама и болничаркама, које су, из осећања хуманости и врхунске етике, вољно и спремно ставиле на располагање своја знања и своје животе да помогну „храброј малој српској армији" (Кокберн 2019: 293). И друго, једнако важно а мање познато, њихова писана заоставштина сведочи о вредном и значајном корпусу дела којима је балканизам, иако доминантни дискурс оновремених (а и каснијих) западноевропских писаних извора о овом делу света, потпуно стран. Србија коју су оне упознале, иако сиромашна и девастирана ратом, није ни налик дивљој земљи, а Срби нису ни крволоци ни варвари. И не само то: препознавши у Србима и њиховом начину живота неке базичне и једноставне вредности, поједине ауторке имају снаге да критичку оштрицу усмере ка сопственим нацијама и да се запитају зашто су се оне тих вредности одрекле. Тако Мадлен де Беноа Сигоаје (2019: 105) у одломку о љубави према породици и обичајима предака у Србији записује: „Празници у њој играју велику улогу; они су спона, шире срдачност и повезују народ искреним пријатељством скоро заборављеним у западним земљама, потресеним и узрујаним бурним немирима прошлог века." На другом месту (2019: 177), описујући бацање сламе по поду куће на Бадње вече, ова ауторка оцењује да ће „тајанствени смисао и поетичност [тог обреда] измаћи хладним духовима нашег окрутног Запада.” Изабел Емзли Хатон (2019:205) Србе назива „природним џентлменима” чији су манири шармантнији од Француза јер „све код њих долази право из срца, док код Француза то долази иг главе," а најбољи одговор балканизму можда ипак даје Флора Сендс, коментаришући љубазни гест двојице војника када је легла на траву да се одмори током паузе у маршу - један јој је дао своје ћебе као простирку, а други савио шињел и наместио јој га уместо јастука:

Понашање српског сељака није нешто што је научено, што зависи од тога да ли је био добро или рђаво васпитан, већ изгледа да је од природе саставни део његов, и као са таквим 
„ХРАБРА МАЛА СРПСКА АРМИЈА“: СРБИ У ОЧИМА ЧЛАНИЦА СТРАНИХ ...

треба рачунати. Људи који нису ништа знали о српском народу више пута су ме питали зар ме није страх да се крећем међу људима за које они мисле да су дивљаци, док је у ствари сасвим супротно томе. Не могу замислити ништа мање вероватно него да ме нападне српски војник. Ја бих се осећала сигурнија шетајући по некој вароши или селу у Србији ма у које доба ноћи него у многим енглеским или европским варошима. (Сендс 2019: 328)

Долазак ових храбрих и пожртвованих жена у ратом захваћену Србију и живот са Србима који су описале у својим делима представљају прворазредни изазов балканизму. Многа од тих дела објављена су у њиховим земљама и пре завршетка рата и свакако су имала снагу да мењају ставове њихових сународника о овом делу света, јер је и током рата и по његовом завршетку на Западу организовано много добротворних догађајима на којима је прикупљана помоћ за Србију. О томе колико је ратно искуство у Србији променило саме чланице страних медицинских мисија и учврстило њихово уверење да су на правом месту најефектније сведочи Елси Инглис у писму сестри:

Кажем ти да су ови људи прави дивови. Осећам се тако мала поред њих да би требало да се сакријем. Бол! Испаштање! Нисте упознали храброст док не видите ове људе како испаштају. Стварно не знам одакле долази ова раса ратника, али могу рећи да су они прави Божији људи. (Инглис 2019: 141)

\section{ЛИТЕРАТУРА}

Дамјановић, Р. (2019). Предговор - Женски поглед на рат. У Странкиње о српском војнику и Србији у Великом рату. Прир. Р. Дамјановић. Нови Сад и Београд: Прометеј и Радио телевизија Србије, 7-15.

Момчиловић, Б. (1993). Британски путници о нашим крајевима у XIX веку. Нови Сад: Матица српска.

Стобарт, М. С. (2016). Пламени мач у Србији и другде. Нови Сад и Београд: Прометеј и Радио телевизија Србије. 
Todorova, M. (1999). Imaginarni Balkan. Beograd: Biblioteka XX vek.

Хатон, И. Е. (2018) Са женском јединицом у Србији, Солуну и Севастопољу. Нови Сад и Београд: Прометеј и Радио телевизија Србије.

Штруценегер, К. К. (2014). Србија у рату 1914-1916. Нови Сад и Београд: Прометеј и Радио телевизија Србије.

\title{
ИЗВОР
}

Странкиње о српском војнику и Србији у Великом рату. (2019). Прир. Р. Дамјановић. Нови Сад и Београд: Прометеј и Радио телевизија Србије.

\section{Milica Spremić Končar}

\author{
'THE GALLANT LITTLE SERBIAN ARMY': THE SERBS AS SEEN BY \\ FEMALE MEMBERS OF FOREIGN MEDICAL MISSIONS IN WORLD WAR I
}

\begin{abstract}
Summary
Leaning on the concept of Balkanism defined by Maria Todorova, this paper looks into fragments from letters, diaries and memoirs written by women doctors and nurses, members of foreign medical missions in Serbia during World War I. Collected in the book entitled Strankinje o srpskom vojniku i Srbiji u Velikom ratu, the fragments show how opposed their authors' opinions and standpoints are to the dominant discourse of the times in which they were written. Instead of the scornful and deprecating attitude that typically dominated the writings about the South Slavonic parts of Europe, the authors collected in this book show understanding and respect for the Serbs and are greatly impressed by the quick Serbian counterstrike that liberated Belgrade from a thirteen-day Austrian occupation in December 1914, by their being good patients, by their patriotism and their humane treatment of Austrian prisoners of war, by their love of home and family, song and the national dance, as well as by their devotion to the Orthodox Christian faith.
\end{abstract}

Key words: World War I, Serbia, Balkanism, women doctors and nurses 